\title{
Ballooning Deformity (Mucoid Degeneration) of Atrioventricular Valves
}

\author{
ARIELA POMERANCE` \\ From the Department of Histopathology, Central Middlesex Hospital, London N.W.10
}

In the past three years several reports have drawn attention to a type of mitral incompetence associated with a peculiar deformity of the mitral valve. This is characterized by an increase in area of the affected leaflets which become voluminous and prolapse into the atrium in systole. Various names or descriptions have been applied to the condition, based either on pathological findings (described as myxomatous transformation or floppy valve syndrome by Read, Thal, and Wendt, 1965, and Read and Thal, 1966; and as billowing sail deformity by Oka and Angrist, 1961) or on cine-angiographic appearances (described as ballooning of posterior leaflet by Linhart and Taylor, 1966, and Behar, Whalen, and McIntosh, 1967; as prolapse of posterior leaflet by Criley et al., 1966, and Stannard et al., 1967; as aneurysmal protrusion and billowing of posterior leaflet by Barlow et al., 1968, and Barlow and Bosman, 1966). It appears identical to the two cases described in 1958 by Fernex and Fernex as mucoid degeneration. Most of these reports have been from centres in the U.S.A. and South Africa, but necropsy observations suggest that similar cases are not uncommon in this country.

\section{SUBJECTS}

The 35 cases seen in the past 6 years consisted of 23 men and 12 women whose ages ranged from 51 to 98 years. Of these, 30 occurred in the 3083 adult necropsies performed in this hospital, an incidence of 1 per cent. The available clinical and pathological data are summarized in the Table. Though the presence of heart murmurs had been known for up to 25 years, none of the patients was under 50 years at death, and the average age was 73.6 years. Their age distribution was similar to that for necropsies generally in this hospital.

Only 16 patients had presented with cardiovascular signs or symptoms. In 5 cardiac failure was clinically

Received December 12, 1968.

$\star$ In receipt of a grant from the British Heart Foundation. considered secondary to pulmonary disease, in 1 to a combination of hepatic and respiratory failure, and in 2 to ischaemic heart disease; 3 patients were thought to have rheumatic valvular disease, and 3 (including one of the rheumatic cases) bacterial endocarditis, 1 congenital heart disease, and 3 "senile" heart failure. Nineteen patients were in cardiac failure on their terminal admission, with atrial fibrillation in 5 patients. None had been hypertensive. Electrocardiograms in 14 patients showed no constant abnormalities. Apart from one (Case 34), who had a large recent infarct, ischaemic changes were reported in 3 patients, only one of whom had complained of angina.

Systolic murmurs had been present in 24 patients; these too had no constant features; descriptions ranged from short apical to loud pansystolic with thrill. The presence of murmurs was not assessable in 7 patients whose heart sounds were either obscured by pulmonary adventitious sounds or were too faint. In 4 patients, heart sounds had been recorded as normal. The murmurs had been attributed to rheumatic heart disease in 3 patients; Cases 25 and 31 had histories of attacks of rheumatic fever, and the rheumatic aetiology in Case 23 was suggested by a radiological finding of calcification in the mitral area (later shown to be in the valve ring). Case 2, a woman aged 51, with longstanding kyphoscoliosis, was thought to have tricuspid incompetence due to right ventricular dilatation, and Case 26, a woman aged 98 , was considered to have mitral ring calcification. Mitral incompetence of undetermined aetiology had been diagnosed in Cases 11, 19, and 35. One patient (Case 5), whose murmur had first been noted 20 years previously, had been labelled "functional", and another (Case 31), also known to have had a murmur since army medical examination 25 years before death, was considered to have congenital heart disease.

Only 2 patients had past histories of rheumatic or scarlet fever (and neither showed evidence of old carditis at necropsy). Cases 7 and 18 had pulmonary tuberculosis and pneumonia, Case 29 had been gassed in the 1914-1918 war, and 6 others were chronic bronchitics.

Family history was non-contributory in most instances. Parents or sibs of 3 patients had died of heart disease, but the nature of this was not ascertained. 


\begin{tabular}{|c|c|c|c|c|c|c|c|c|}
\hline $\begin{array}{l}\text { Case } \\
\text { No. }\end{array}$ & $\begin{array}{l}\text { Age } \\
\text { (yr.) }\end{array}$ & Sex & Clinical presentation & Cause of death & $\begin{array}{l}\text { Past medical and family } \\
\text { history }\end{array}$ & $\begin{array}{c}\text { Blood } \\
\text { pressure } \\
(\mathrm{mm} . \mathbf{H g})\end{array}$ & Pulse & $\begin{array}{l}\text { Cardiac } \\
\text { failure }\end{array}$ \\
\hline 1 & 54 & $\mathbf{M}$ & Cor pulmonale; & Bronchopneumonia and & Congenital kyphoscoliosis & $?$ & $?$ & + \\
\hline 2 & 51 & $\mathbf{F}$ & $\begin{array}{c}\text { kyphoscoliosis } \\
\text { Cor pulmonale; } \\
\text { kyphoscoliosis }\end{array}$ & $\begin{array}{l}\text { cardiac failure } \\
\text { Pulmonary thrombosis, } \\
\text { cardiac failure }\end{array}$ & Potts disease at $3 \mathrm{yr}$. & $130 / 90$ & Fibrillating & + \\
\hline 3 & 69 & $\mathbf{F}$ & Coma and pyrexia & $\begin{array}{l}\text { Staphylococcal endocar- } \\
\text { ditis with multiple }\end{array}$ & None obtained & $120 / 90$ & Regular & + \\
\hline 4 & 80 & $\mathbf{F}$ & Pleural effusion & $\begin{array}{l}\text { Carcinoma of bronchus } \\
\text { with metastases }\end{array}$ & None obtained & $130 / 70$ & Regular & + \\
\hline 5 & 58 & $\mathbf{M}$ & Retention of urine & $\begin{array}{l}\text { Carcinoma of prostate } \\
\text { with metastases }\end{array}$ & $\begin{array}{l}\text { Angina for } 5 \mathrm{yr} \text {; ; rejected } \\
\text { for military service } 20 \\
\text { yr. ago because of } \\
\text { “murmur" }\end{array}$ & $170 / 90$ & Regular & - \\
\hline 6 & 83 & $\mathbf{F}$ & Dyspnoea and backache & Pulmonary embolism & None obtained & $120 / 90$ & Fibrillating & + \\
\hline 7 & 81 & $\mathbf{M}$ & $\begin{array}{l}\text { Acute-on-chronic } \\
\text { bronchitis }\end{array}$ & Carcinoma of bronchus & Old pulmonary TB & $130 / 70$ & Regular & - \\
\hline 8 & 63 & $\mathbf{M}$ & $\begin{array}{l}\text { Acute-on-chronic } \\
\text { bronchitis }\end{array}$ & Cardiac failure & None relevant & $160 / 80$ & Regular & + \\
\hline 9 & 84 & $\mathbf{F}$ & Arteriosclerotic & Bronchopneumonia & None relevant & $130 / 90$ & Regular & - \\
\hline $\begin{array}{l}10 \\
11\end{array}$ & $\begin{array}{l}90 \\
62\end{array}$ & $\begin{array}{l}\mathbf{M} \\
\mathbf{M}\end{array}$ & $\begin{array}{l}\text { Senile dementia } \\
\text { Cerebral tumour }\end{array}$ & $\begin{array}{l}\text { Bronchopneumonia } \\
\text { Metastases from carcin- } \\
\text { oma of bronchus }\end{array}$ & $\begin{array}{l}\text { None obtained } \\
\text { None obtained }\end{array}$ & $\begin{array}{l}140 / 70 \\
120 / 90\end{array}$ & $\begin{array}{l}\text { Regular } \\
\text { Regular }\end{array}$ & $\overline{-}$ \\
\hline 12 & 79 & $\mathbf{M}$ & Cardiac failure & $\begin{array}{c}\text { Cardiac failure, bronchitis, } \\
\text { pulmonary embolism }\end{array}$ & None obtained & $?$ & $?$ & + \\
\hline 13 & 84 & $\mathbf{M}$ & Laryngeal stridor & $\begin{array}{l}\text { Acute pancreatitis, } \\
\text { tracheobronchitis }\end{array}$ & $\begin{array}{l}\text { Previous attacks of } \\
\text { cardiac failure }\end{array}$ & $130 / 80$ & Regular & + \\
\hline 14 & 89 & $\mathbf{F}$ & Scleroderma & Carcinoma of bronchus & None relevant & $100 / 70$ & Regular & - \\
\hline 15 & 76 & $\mathbf{M}$ & Carcinoma of bronchus & Carcinoma of bronchus & None relevant & $140 / 70$ & Regular & - \\
\hline 16 & 61 & $\mathbf{M}$ & Dyspnoea & $\begin{array}{l}\text { Carcinoma of bronchus } \\
\text { with metastases }\end{array}$ & None relevant & $100 / 70$ & Regular & - \\
\hline 17 & 84 & $\mathbf{F}$ & $\begin{array}{l}\text { Abdominal pain, } \\
\text { distension }\end{array}$ & Carcinoma of stomach & $\begin{array}{l}\text { Parent died at } 33 \text { from } \\
\text { "heart trouble" }\end{array}$ & $190 / 90$ & Regular & - \\
\hline 18 & 87 & $\mathbf{M}$ & Coma and hypothermia & Bronchopneumonia & $\begin{array}{c}\text { Pneumonia } 20 \mathrm{yr} . \\
\text { previously }\end{array}$ & $130 / 70$ & Regular & + \\
\hline 19 & 79 & $\mathbf{M}$ & Chest pain & Carcinoma of bronchus & None relevant & $170 / 100$ & Regular & - \\
\hline 20 & 83 & $\mathbf{M}$ & Urinary symptoms & $\begin{array}{l}\text { Bronchopneumonia and } \\
\text { suppurative } \\
\text { pyelonephritis }\end{array}$ & Several yr. "heart trouble" & $120 / 70$ & Regular & + \\
\hline 21 & 54 & $\mathbf{M}$ & Chest and neck pain & Carcinoma of bronchus & None relevant & $180 / 95$ & Regular & - \\
\hline 22 & 63 & $\mathbf{F}$ & Asthma & $\begin{array}{l}\text { Haemorrhage from gastric } \\
\text { ulcer }\end{array}$ & None obtained & $125 / 75$ & Regular & - \\
\hline 23 & 58 & $\mathbf{M}$ & $\begin{array}{l}\text { Cardiac and hepatic } \\
\text { failure }\end{array}$ & $\begin{array}{l}\text { Cardiac failure and } \\
\text { cirrhosis of liver }\end{array}$ & $\begin{array}{l}\text { Chronic bronchitis and } \\
\text { heavy drinking }\end{array}$ & $110 / 100$ & Fibrillating & + \\
\hline 24 & 85 & $\mathbf{F}$ & Pneumonia, & Bronchopneumonia & None obtained & $?$ & $?$ & $?$ \\
\hline 25 & 98 & $\mathbf{F}$ & Recurrent hemiplegia & $\begin{array}{l}\text { Cerebral infarction and } \\
\text { bronchopneumonia }\end{array}$ & $\begin{array}{l}\text { Rheumatic fever at } 15 \text { and } \\
40 \text { yr.; cardiac symp- } \\
\text { toms } 15 \text { yr.; mother } \\
\text { and brother died in } 50 \text { 's } \\
\text { of "hearts" } \\
\text { None obtained }\end{array}$ & $110 / 70$ & Fibrillating & + \\
\hline $\begin{array}{l}27 \\
28\end{array}$ & $\begin{array}{l}60 \\
73\end{array}$ & $\stackrel{M}{M}$ & $\begin{array}{l}\text { pancytopenia } \\
\text { Carcinomatosis } \\
\text { Abdominal pain }\end{array}$ & $\begin{array}{l}\text { Carcinoma of pancreas } \\
\text { Carcinoma of caecum }\end{array}$ & $\begin{array}{l}\text { None obtained } \\
\text { None relevant }\end{array}$ & $\begin{array}{l}110 / 60 \\
160 / 80\end{array}$ & $\begin{array}{l}\text { Regular } \\
\text { Regular }\end{array}$ & $\overline{-}$ \\
\hline 29 & 84 & $\mathbf{M}$ & $\begin{array}{l}\text { Cardiac failure, } \\
\text { gangrene }\end{array}$ & $\begin{array}{l}\text { Aortic thrombosis and } \\
\text { carcinoma prostate }\end{array}$ & Gassed in $1914-1918$ war & $130 / 80$ & Regular & + \\
\hline 30 & 63 & $\mathbf{M}$ & Sudden death & $\begin{array}{l}\text { Cardiac failure; ruptured } \\
\text { chorda tendinea }\end{array}$ & $\begin{array}{l}\text { Several yr. progressive } \\
\text { cardiac failure; murmur } \\
\text { in army medical } 25 \mathrm{yr} \text {. }\end{array}$ & $120 / 90$ & Regular & + \\
\hline 31 & 79 & $\mathrm{~F}$ & $\begin{array}{l}\text { Cardiac failure (thought } \\
\text { to be rheumatic) }\end{array}$ & Cardiac failure & Rheumatic fever & $150 / 90$ & Regular & + \\
\hline 32 & 61 & $\mathbf{M}$ & $\begin{array}{l}\text { Cardiac failure and } \\
\text { cerebral signs }\end{array}$ & $\begin{array}{l}\text { Emboli from bacterial } \\
\text { endocarditis }\end{array}$ & $\begin{array}{l}\text { Dyspnoeic for } 4 \text { yr; ; } \\
\text { mother died of "heart } \\
\text { trouble" }\end{array}$ & $120 / 90$ & Regular & + \\
\hline 33 & 57 & $\mathbf{M}$ & Jaundice, cardiac failure & $\begin{array}{l}\text { Cardiac failure; acute-on- } \\
\text { chronic bronchitis }\end{array}$ & Chronic bronchitic & $90 / 65$ & Fibrillating & + \\
\hline 34 & 84 & $\mathbf{M}$ & Acute myocardial infarct & Myocardial infarction & None obtained & $110 / 70$ & Regular & + \\
\hline 35 & 78 & $\mathbf{M}$ & $\begin{array}{l}\text { Chest pain, cardiac } \\
\text { failure, cyanosis, leg } \\
\text { vein thrombosis }\end{array}$ & $\begin{array}{l}\text { Cardiac failure; pulmon- } \\
\text { ary embolism and } \\
\text { thrombosis; ruptured } \\
\text { chordae tendineae }\end{array}$ & $\begin{array}{l}\text { A } 10 \text {-yr. previous admis- } \\
\text { sion and } 2 \text { recent ones } \\
\text { (for pulmonary embol- } \\
\text { ism from deep leg veins) }\end{array}$ & $150 / 100$ & Regular & + \\
\hline
\end{tabular}




\begin{tabular}{|c|c|c|c|c|}
\hline Murmurs & ECG findings & $\begin{array}{l}\text { Heart } \\
\text { weight } \\
\text { (g.) }\end{array}$ & Extent of ballooning & Other pathological changes \\
\hline ? (heart sounds obscured) & - & 410 & Both AV valves, all cusps & - \\
\hline $\begin{array}{l}\text { Loud pansystolic, noted } 6 \text { yr. previ- } \\
\text { ously (diagnosed as tricuspid } \\
\text { incompetence) }\end{array}$ & Atrial fibrillation & 300 & Both AV valves, all cusps & Fibrinous endocarditis \\
\hline $\begin{array}{l}\text { Mitral pansystolic with prediastolic } \\
\text { crescendo (diagnosed as mitral } \\
\text { incompetence) } \\
\text { ? (heart sounds faint) }\end{array}$ & - & $\begin{array}{l}350 \\
300\end{array}$ & $\begin{array}{l}\text { Pusterior cusp mitral only } \\
\text { Posterior cusp mitral only }\end{array}$ & $\begin{array}{l}\text { Bacterial endocarditis with ruptured } \\
\text { chordae tendineae } \\
\text { - }\end{array}$ \\
\hline $\begin{array}{l}\text { Harsh systolic, maximal at apex } \\
\text { (diagnosed as functional) }\end{array}$ & Normal & 360 & $\begin{array}{l}\text { Both cusps mitral, most marked } \\
\text { in posterior }\end{array}$ & Fibrinous endocarditis \\
\hline Loud apical systolic, conducted & Suggestive of old & 400 & Both cusps mitral & Marked left atrial dilatation \\
\hline $\begin{array}{l}\text { toward axilla } \\
\text { ? (heart sounds obscured) }\end{array}$ & infarction & $?$ & $\begin{array}{l}\text { Posterior cusp mitral and an- } \\
\text { terior and septal cusps tri- } \\
\text { cuspid }\end{array}$ & $\begin{array}{l}\text { Post-inflammatory adhesions of } \\
\text { mitral commissures (slight) and } \\
\text { vascularization of mitral cusp }\end{array}$ \\
\hline ? (heart sounds obscured) & Normal & 230 & $\begin{array}{l}\text { Posterior cusp and medial half } \\
\text { anterior cusp mitral }\end{array}$ & $\begin{array}{l}\text { Marked dilatation left atrium; pos- } \\
\text { terior cusp chordae adherent to } \\
\text { ventricular wall, with active }\end{array}$ \\
\hline Short apical systolic & 一 & 270 & Both cusps mitral & inflammatory changes still visible \\
\hline $\begin{array}{l}\text { Doubtful apical diastolic } \\
\text { Loud apical pansystolic, also heard } 1 \\
\text { yr. previously (diagnosed as mitral } \\
\text { incompetence) }\end{array}$ & Normal - & $\begin{array}{l}300 \\
320\end{array}$ & $\begin{array}{l}\text { Mainly posterior cusp mitral } \\
\text { Posterior cusp mitral only }\end{array}$ & $\begin{array}{l}\text { Old myocardial infarct } \\
\text { Large area of endocardial roughen- } \\
\text { ing with adherent fibrin on pos- } \\
\text { terior wall of left atrium }\end{array}$ \\
\hline Apical systolic & - & 510 & Both cusps mitral & $\begin{array}{l}\text { Minor congenital chordae tendineae } \\
\text { abnormalities; small area myo- } \\
\text { cardial infarction }\end{array}$ \\
\hline $\begin{array}{l}\text { ? (heart sounds obscured) but apical } \\
\text { systolic } 4 \text { yr. previously }\end{array}$ & - & 490 & Both cusps mitral & $\begin{array}{l}\text { Roughening of left atrial posterior } \\
\text { wall endocardium with adherent } \\
\text { fibrin }\end{array}$ \\
\hline $\begin{array}{l}\text { Systolic, at junction of apex and } \\
\text { aortic area; first heard } 5 \text { yr. previ- } \\
\text { ously }\end{array}$ & - & 220 & Mainly posterior cusp mitral & $\begin{array}{l}\text { Endocardial "pocket" anterior cusp } \\
\text { mitral, also small aneurysm mem- } \\
\text { branous septum }\end{array}$ \\
\hline None heard & - & 250 & Posterior cusp mitral only & $\begin{array}{l}\text { Fibrous "jet" lesion anterior mitral } \\
\text { cusp }\end{array}$ \\
\hline None heard & - & 310 & Posterior cusp and mild & 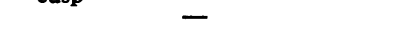 \\
\hline None heard & - & 270 & Posterior cusp mitral only & 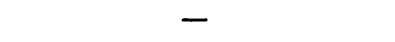 \\
\hline $\begin{array}{l}\text { Systolic (details obscured by adven- } \\
\text { titious sounds) }\end{array}$ & - & 330 & $\begin{array}{l}\text { Both cusps mitral and mild } \\
\text { anterior cusp tricuspid }\end{array}$ & - \\
\hline $\begin{array}{l}\text { Harsh systolic, maximal 4th space } \\
\text { conducted to axilla (diagnosed as } \\
\text { mitral incompetence) }\end{array}$ & $\begin{array}{l}\text { Incomplete left } \\
\text { bundle-branch } \\
\text { block }\end{array}$ & 320 & $\begin{array}{l}\text { Both cusps mitral and slight } \\
\text { changes anterior tricuspid }\end{array}$ & Congenital abnormalities of chordae \\
\hline Apical pansystolic & $\begin{array}{l}\text { Suggestive of } \\
\text { digitalis } \\
\text { overdosage }\end{array}$ & 240 & Posterior cusp mitral only & - \\
\hline None heard & - & 320 & $\begin{array}{l}\text { Mainly posterior cusp mitral, } \\
\text { slight anterior cusp only }\end{array}$ & $\begin{array}{l}\text { Small vegetation on thickened area } \\
\text { on anterior mitral cusp }\end{array}$ \\
\hline ? (heart sounds faint) & 一 & 310 & Posterior cusp mitral only & \\
\hline $\begin{array}{l}\text { Loud apical systolic with thrill over } \\
\text { mitral area (diagnosed as mitral } \\
\text { incompetence) }\end{array}$ & $\begin{array}{l}\text { LV hypertrophy } \\
\text { and atrial } \\
\text { fibrillation }\end{array}$ & 670 & $\begin{array}{l}\text { Both cusps mitral and slight } \\
\text { changes anterior tricuspid }\end{array}$ & $\begin{array}{l}\text { Fibrinous endocarditis mainly over } \\
\text { severe ring calcification ulcerating } \\
\text { through cusp; congenital aortic } \\
\text { cusp fusion }\end{array}$ \\
\hline $\begin{array}{l}\text { Mitral pansystolic, conducted to } \\
\text { axilla }\end{array}$ & - & 250 & & \\
\hline $\begin{array}{l}\text { Apical pansystolic conducted to axilla, } \\
\text { and softer mid-diastolic (diagnosed } \\
\text { as mitral stenosis and incompet- } \\
\text { ence) }\end{array}$ & Atrial fibrillation & 420 & $\begin{array}{l}\text { Both cusps mitral and anterior } \\
\text { tricuspid }\end{array}$ & $\begin{array}{l}\text { Marked left atrial dilatation; atrial } \\
\text { septal defect; severe mitral ring } \\
\text { calcification }\end{array}$ \\
\hline $\begin{array}{l}\text { Apical pansystolic (diagnosed as } \\
\text { mitral ring calcification) }\end{array}$ & 一 & 230 & $\begin{array}{l}\text { Both cusps mitral and slight } \\
\text { changes anterior tricuspid }\end{array}$ & $\begin{array}{l}\text { Small foci fibrinous endocarditis } \\
\text { both mitral cusps }\end{array}$ \\
\hline $\begin{array}{l}\text { Soft apical systolic } \\
\text { Soft apical systolic }\end{array}$ & ? Ischaemia & $\begin{array}{l}250 \\
370\end{array}$ & $\begin{array}{l}\text { Both cusps mitral } \\
\text { Mainly posterior cusp mitral }\end{array}$ & $\begin{array}{l}\text { Brown atrophy of myocardium } \\
\text { Old "jet" lesions posterior wall of }\end{array}$ \\
\hline ? (heart sounds obscured) & 一 & $?$ & Both cusps mitral & $\begin{array}{l}\text { Fibrous adhesions of postero-lateral } \\
\text { chordae tendineae to posterior wall } \\
\text { of left ventricle }\end{array}$ \\
\hline $\begin{array}{l}\text { Loud praecordial systolic with thrill } \\
\text { (diagnosed as congenital, probably } \\
\text { ventricular septal defect) }\end{array}$ & $\begin{array}{l}\text { No significant } \\
\text { abnormality }\end{array}$ & 610 & Both cusps mitral & $\begin{array}{l}\text { Rupture of } 2 \text { postero-medial chordae } \\
\text { tendineae; fibrinous endocarditis }\end{array}$ \\
\hline $\begin{array}{l}\text { Pansystolic in mitral area, conducted } \\
\text { to axilla (diagnosed as rheumatic } \\
\text { mitral incompetence) }\end{array}$ & - & 435 & $\begin{array}{l}\text { Both cusps mitral mainly an- } \\
\text { terior, and anterior and sep- } \\
\text { tal tricuspid cusps }\end{array}$ & $=0$ \\
\hline $\begin{array}{l}\text { Apical pansystolic conducted to axilla } \\
\text { and neck }\end{array}$ & Ischaemic changes & 710 & $\begin{array}{l}\text { Both cusps mitral, mainly } \\
\text { posterior }\end{array}$ & $\begin{array}{l}\text { Bacterial endocarditis both cusps } \\
\text { mitral }\end{array}$ \\
\hline ? (sounds inaudible) & 一 & 460 & Both cusps mitral & 一 \\
\hline Apical systolic & Anterior infarct. & ? & Both cusps mitral, mainly & Myocardial infarction \\
\hline $\begin{array}{l}\text { Loud apical systolic conducted to } \\
\text { axilla (diagnosed as dilatation of } \\
\text { mitral ring) }\end{array}$ & $\begin{array}{l}\text { Occasional ectopic } \\
\text { beats; tall P } \\
\text { waves, lead III }\end{array}$ & 450 & $\begin{array}{l}\text { posterior } \\
\text { Both cusps mitral, mainly } \\
\text { posterior }\end{array}$ & $\begin{array}{l}\text { Rupture of } 3 \text { postero-medial chordae } \\
\text { tendineae; mitral ring calcification }\end{array}$ \\
\hline
\end{tabular}




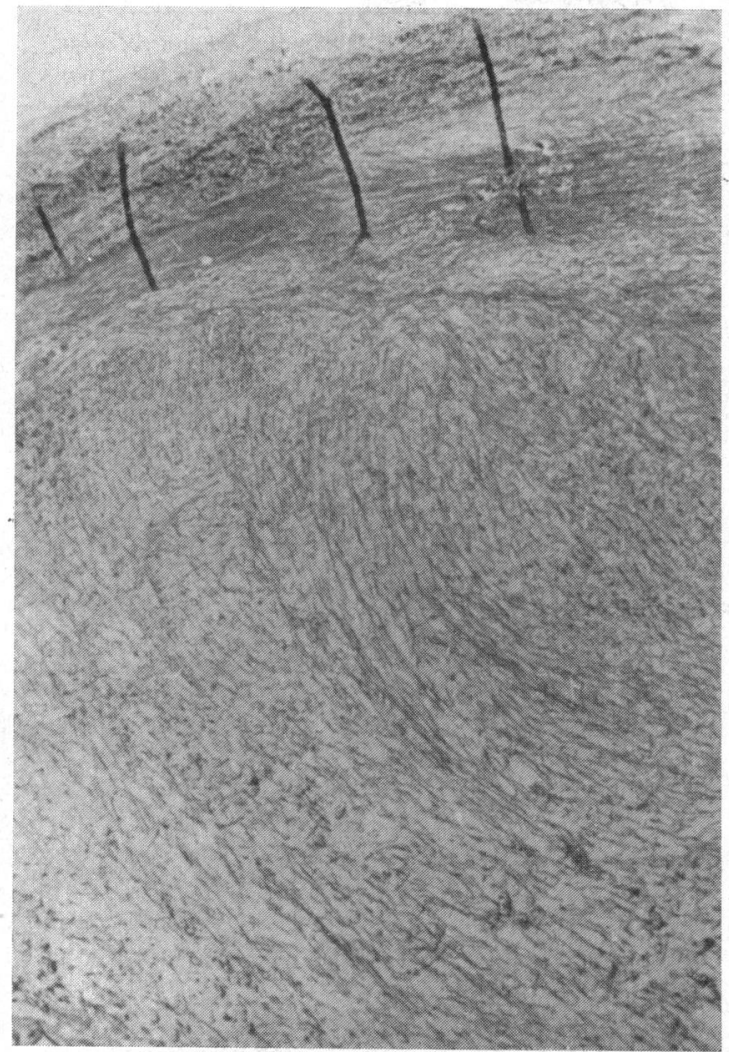

FIG. 1.-Photomicrograph of part of a mitral cusp showing loose myxomatoid tissue replacing the fibrosa. A narrow zone of normal collagen remains immediately below the atrialis. (Haematoxylin and eosin. $\times 290$.)

\section{Pathology}

The hearts were mainly of normal size, weights ranging from $220-710$ g., average 366 g. In 23 cases, both cusps of the mitral valve were voluminous, opaque, and thickened, resembling a parachute. This ballooning deformity tended to be more conspicuous in the posterior cusp, which was often of larger area than the anterior. In 11 cases only the posterior cusp was macroscopically affected. Similar but less well marked changes were seen in one or more of the tricuspid valve cusps in 9 patients. Microscopically the affected cusps showed replacement of the fibrosa by a loose metachromatically staining myxomatous tissue with fibro-elastic thickening of the surrounding endocardium (Fig. 1). Both these changes were present in variable degrees in all the affected valves, but the basic abnormality appeared to be the fibrosal degeneration. Loss of this normally dense collagenous supporting structure would clearly allow stretching of the cusp by normal variations in intraventricular pressures, and would result in the characteristic voluminous ballooned leaflets. The accompanying fibro-elastic proliferation was of the non-specific type associated with various haemodynamic stimuli (McMillan and Lev, 1959; Pomerance, 1967) and presumably provoked by the stretching process.

Superficial fibrinous "endocarditis" was seen in 10 patients (Fig. 2). The lesions consisted of foci of amorphous eosinophilic material, staining as fibrin, either in the atrialis, or adherent to atrial endocardium. Red blood cells were often present in the deeper lesions but no inflammatory reaction was seen. Bacterial endocarditis was present in 2 patients, both dying of systemic emboli. The infecting organism in Case 3 was Staph. pyogenes, and in Case 32 (Fig. 3) a non-haemolytic streptococcus. Three cases had ruptured posterior group chordae tendineae; in Case 3 this had occurred under a staphylococcal vegetation, but Cases 30 and 35 (Fig. 4) had no evidence of current or previous bacterial infection. Subvalvular areas of opaque white thickening were present in the posterior wall of the left ventricle in two hearts. These involved the adjacent chordae tendineae, which had become adherent to the ventricular endocardium, and in Case 8 chronic inflammatory cells were still visible in the abnormal fibrous tissue. Case 7 was the only example of previous valvulitis-slight adhesions were present at both mitral commissures, with macroscopical and microscopical vascularization of the anterior cusp.

Striking anatomical evidence of mitral incompetence was seen in 8 patients, 3 of whose hearts showed gross left atrial dilatation, and "jet" lesions were present on atrial walls or anterior mitral cusps in 6 .

\section{Other Cardiac Pathology}

Coronary embolism had occurred in Case 32, resulting in a giant cell myocarditis and pericarditis. Coronary atherosclerosis appeared less than expected in patients of this age-group. Case 34 was the only patient dying with an extensive recent myocardial infarct, though a small area of recent infarction was also present in Case 12, and an old fibrotic lesion was seen in Case 10. The coronary arteries were almost free from atheroma in 8 cases and showed mild narrowing only in a further 7. Marked atherosclerotic changes were present in only 8 of the 35 cases. The only other abnormality encountered with any frequency was calcification of the mitral valve ring, present in 9 cases, but severe in only 3 (Fig. 5); 8 of these were over 70 years, and the incidence was no higher than anticipated in this age- 


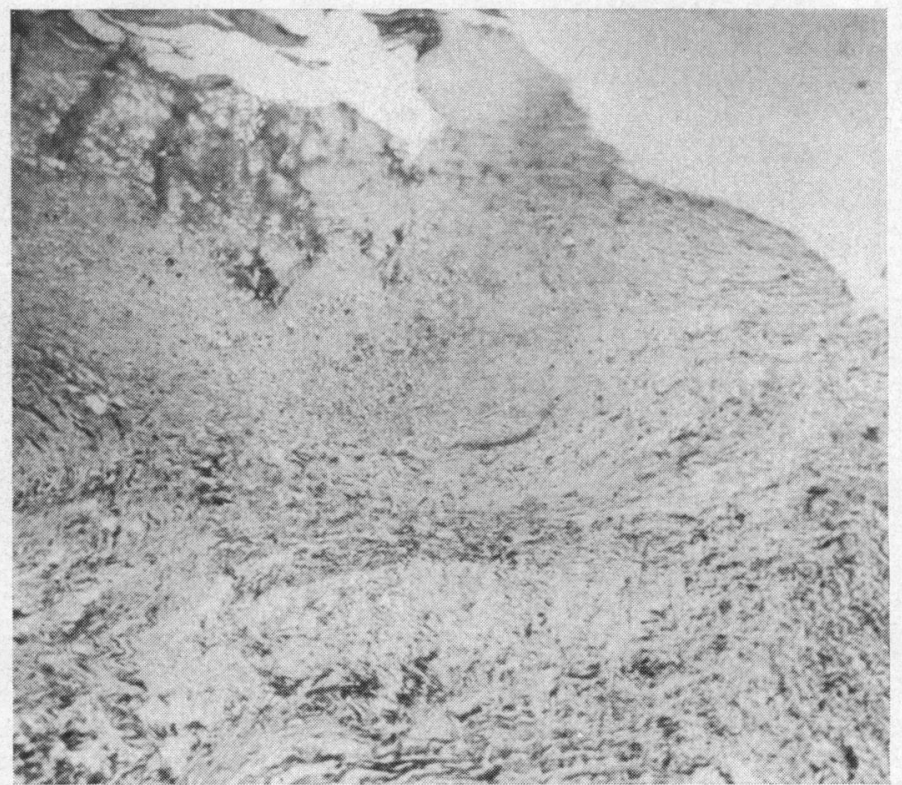

FIG. 2.-Photomicrograph showing tearing with fibrin and red blood cells in superficial zone of mitral valve atrialis. (Haematoxylin and eosin. $\times 470$.)

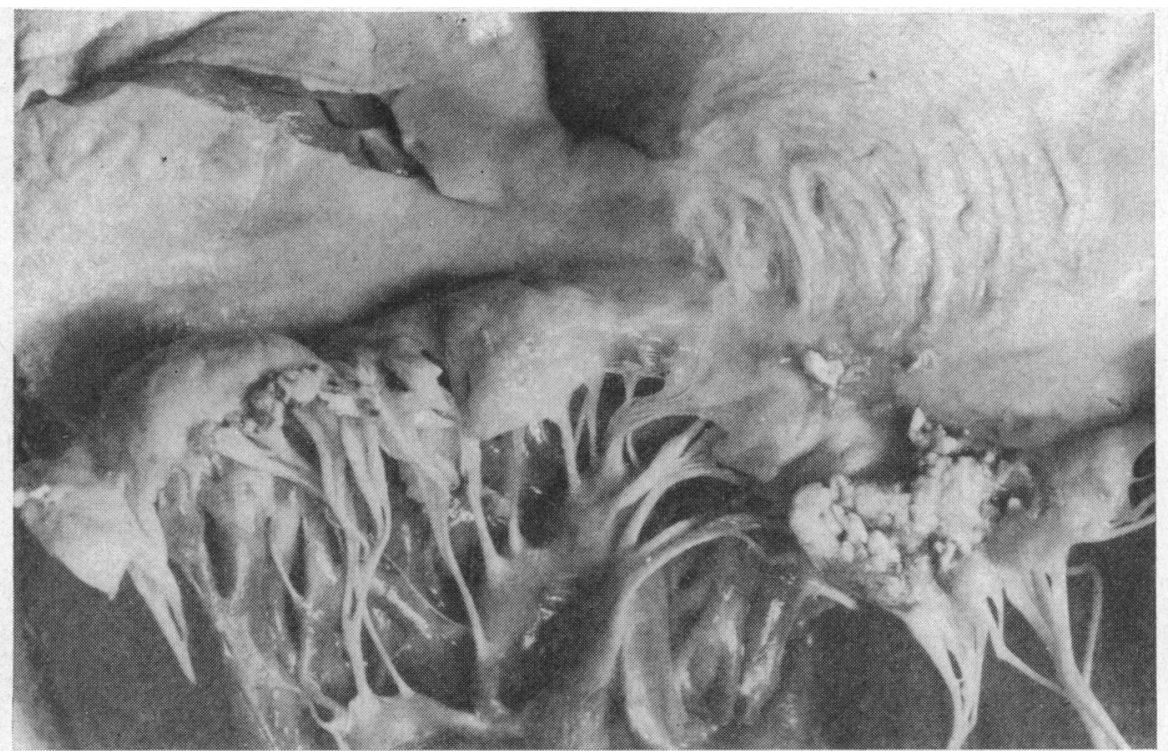

Fig. 3.-Opened left side of heart showing ballooning, more marked in the posterior cusp, with large vegetations on both cusps. An area of thick ridged endocardium above the anterior cusp indicates chronic mitral incompetence. Case 32, a man aged 61 admitted complaining of severe dyspnoea, palpitations, and loss of weight for 4 months. Dyspnoea on exertion had been present for 4 years. He was pyrexial, in congestive failure, and had a loud apical pansystolic murmur, conducted to axilla and carotids. Other signs and symptoms suggesting renal and cerebral embolism were present, and blood culture yielded a non-haemolytic streptococcus. He became apyrexial on antibiotics, but emboli continued and he died with multiple infarcts, including cerebral. 
group. Case 23 (Fig. 6) was a comparatively young anomalous chordae tendineae in 2 and single man, who also had hepatic cirrhosis. Brown examples of atrial septal defect, aneurysm of mematrophy was noted in 1 case, and 5 hearts had rela- branous interventricular septum, and bicuspid tively minor congenital abnormalities consisting of aortic valve in the other 3.

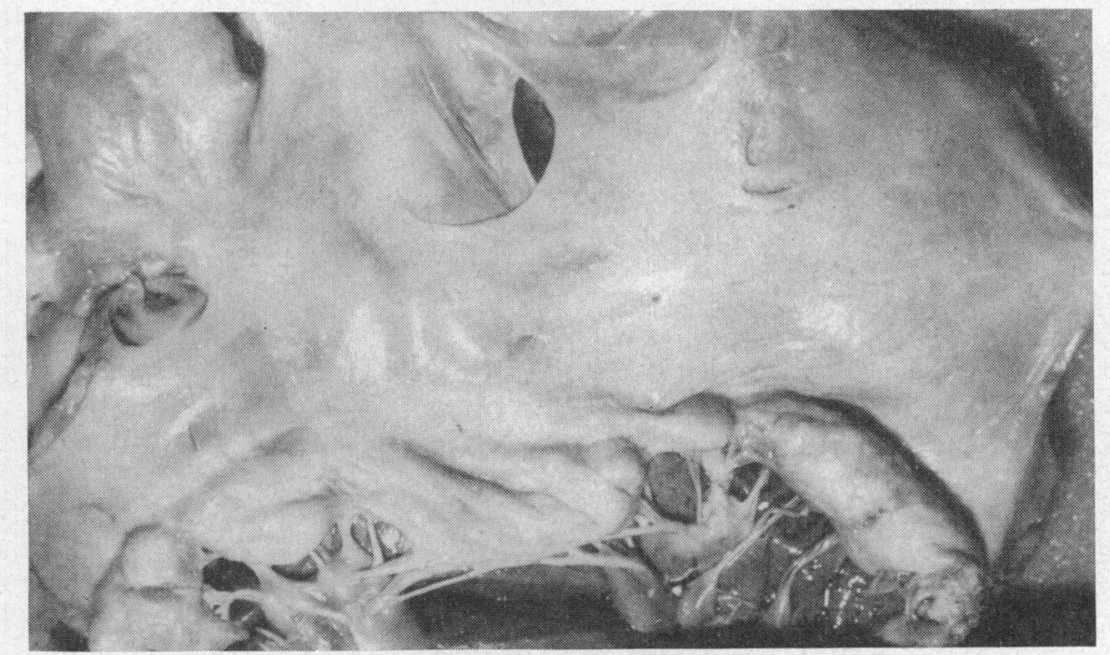

FIG. 5.-Part of opened left side of heart showing an atrial septal defect, and ballooning deformity of both mitral cusps. The posterior cusp is further distorted by a bar of calcification originating in the valve ring. No adhesions of commissures or chordae are present. Case 25, a woman aged 75, admitted with recurrent hemiplegia. She had a history of rheumatic fever at 15 and 40 years, but no further cardiac symptoms until 60 years. She was fibrillating but not in failure, and had an apical pansystolic murmur, conducted to axilla, and mid-diastolic murmur. These were attributed to rheumatic mitral stenosis and incompetence. Death was due to bronchopneumonia and cerebral infarction. 


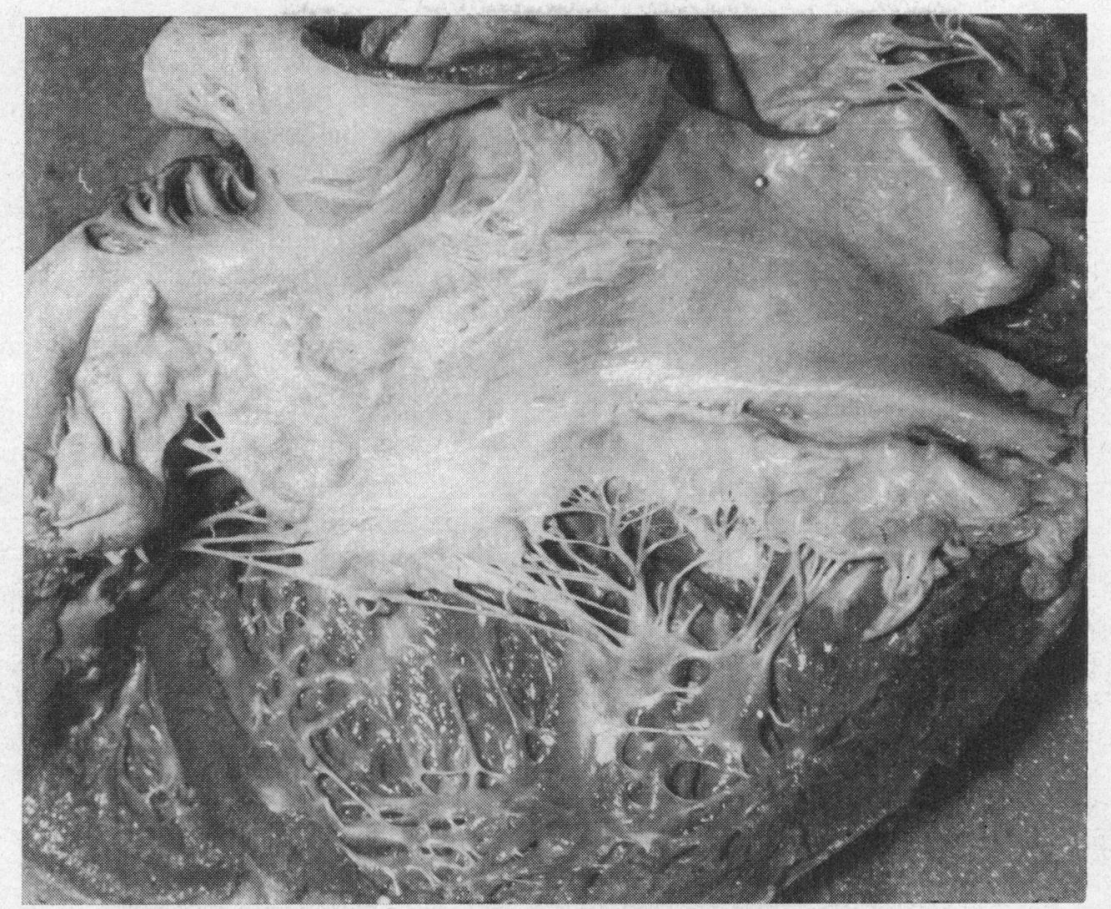

FIG. 6.-Opened left side of heart showing ballooned and floppy mitral valve. Spurs of calcium extend from the ring and distort the posterior cusp. Small patches of endocardial fibrosis are seen high on the posterior wall of the ventricle. Case 23, a man of 58 with two years of progressive cardiac failure and a loud systolic murmur over the whole praecordium, conducted to axilla. Calcification in the mitral area was seen on screening, and a diagnosis of rheumatic mitral disease was made. He was a longstanding epileptic and chronic bronchitic, and drank 15 pints of Guinness daily. Death was due to combined cardiac and hepatic failure.

\section{Discussion}

There is no doubt about the identity of cases where affected cusps were examined pathologically, and it is difficult to envisage any process other than softening of cusp fibrosa which could produce a ballooning, billowing, or prolapsing appearance on cine-angiography. Stannard et al. (1967) also believed the anatomical deformity to be enlargement of cusps; this was confirmed in the only patient who subsequently came to necropsy (Barlow et al., 1968).

Review of clinical findings in the present series showed no constant features which might assist detection of the ballooning deformity. Until recently the condition was not recognized as a clinical problem, but Behar et al. (1967) and Linhart and Taylor (1966) suggest that it may not be uncommon. Behar et al. (1967) showed ballooning in 6 per cent of cardiac clinic patients. In this hospital some degree was found in 4.5 per cent of necropsies on elderly patients with systolic murmurs (Pomerance, 1968). However, even knowing its comparatively high incidence, clinical differentiation between ballooning, ring calcification, and other less common causes of mitral incompetence was not possible. As in clinical reports (Behar et al., 1967), murmurs had ranged from short apical to diffuse pansystolic with thrills. Neither intensity nor localization could be related to severity of abnormality; both patients with thrills had had severe ballooning of both mitral cusps, but equally severe changes were present in cases without thrills.

Though all had a severe degree of ballooning, only 19 cases were in failure and those without cardiac symptoms included 4 of 8 with gross left atrial dilatation or "jet" lesions. This finding, together with a high average age compared with the clinical series, confirms views (Linhart and Taylor, 1965; Stannard et al., 1967) that this type of mitral incompetence is relatively benign. The predisposition to bacterial endocarditis and spontaneous rupture of chordae tendineae was also confirmed, but review of clinical data showed nothing to distinguish patients in whom mucoid degeneration proved fatal 
from those in whom it remained a benign condition.

The contrasting sex incidence in necropsy (23 men: 12 women) and clinical $(17: 32)$ series is less easily explained. Possibly women develop symptoms and complications earlier than men, but the total number of cases is, as yet, too small for speculation. Furthermore, cases complicated by rupture of chordae tendineae occurred predominantly in men. The appearances in the cases of Marchand et al. (1966) were characteristic of mucoid degeneration; 5 of the 6 were men, as were both my cases.

The predisposition to bacterial endocarditis noted in clinical reports (Read et al., 1965; Read and Thal, 1966; Linhart and Taylor, 1966) was confirmed in our necropsy series, and pathological examination offered an explanation, since fibrinous "endocarditis" was seen in 10 cases. The endocardial damage appeared secondary to the underlying fibrosal changes. With transformation of this normally rigid plate into loose myxomatous tissue the cusp would be stretched by normal intraventricular pressure changes. Overlying endocardium would inevitably also be subjected to abrupt changes in tension, and resulting loss of endothelial continuity and rupture of subendothelial connective tissue fibres would invite the deposition of fibrin seen in these cases.

The pathogenesis of mucoid degeneration of heart valves is unknown. It seems unrelated to rheumatic fever or any particular past illnesses, and no histological evidence of past inflammation has been found. A similar change occurs in Marfan's syndrome (Goyette and Palmer, 1953; Shankar et al., 1967), and Read et al. (1965) suggested that it might therefore be a "forme fruste". Most of their 9 patients or their families had some of the musculoskeletal stigmata, but few patients in other series have shown similar findings. Furthermore, these valve changes have also been reported in other congenital heart diseases and in normal infants (Shankar et al., 1967), and small areas of similar metachromatically staining material are often seen in random post-mortem sections at all ages.

In some reported cases ballooning does seem genetically determined (Read et al., 1965; Stannard et al., 1967; Linart and Taylor, 1966, Barlow et al., 1968), but these seem a minority. Marchand et al. (1966) also thought that the abnormality was congenital, and they are supported by the early age at which some murmurs were first heard. However, most necropsy cases have been elderly; it seems improbable that Case 26, for example, with gross left atrial dilatation, could have survived 98 years if her mitral deformity had been congenital.

In contrast, Oka and Angrist (1961) suggested that the deformity was an ageing change. A similar condition in dogs (Pomerance and Whitney, 1969) is strikingly related to advanced age. Though a slight increase in the comparatively common localized areas of ballooning occurs in men (Pomerance, 1967), no definite correlation with age was demonstrated in severe ballooning. The highest incidence was between 80 and 90 years, but in the 50-69 year groups it was greater than between 70-79 years. Furthermore, a third of cases diagnosed at operation or cine-angiography were under 30 , and almost all were under 50 years.

It appears, therefore, that the small number of cases studied includes individuals providing evidence both supporting and contradicting any proposed pathogeneses, which suggests that there is no single cause of mucoid degeneration of valves. The most satisfactory explanation of currently available facts is that this is simply a tissue reaction, comparable to endocardial fibro-elastic thickening, and similarly the end result of many aetiological factors, including both congenital and ageing changes as well as a variety of diseases of intermediate ages.

\section{SUMMARY}

A severe ballooning deformity of the mitral valve was found in 1 per cent of necropsies over a sixyear period. The 35 cases ( 23 men, 12 women) were aged between 51 and 98 years. Clinical presentation had been varied, and only 19 cases had been in failure. Systolic murmurs, heard in twothirds of the patients, showed no diagnostic characteristics and were not related to severity of valvular deformity. Electrocardiograms were non-contributory. The pathological changes ranged from enlargement of the posterior cusp only, to involvement of the tricuspid valve as well as both mitral cusps. Microscopy showed replacement of cusp fibrosa by metachromatically staining loose myxomatous material, with fibro-elastic thickening of adjacent endocardium. Fibrinous "endocarditis" was common and appeared secondary to stretching of a fibrosa no longer able to resist intraventricular systolic pressures. Two cases were complicated by bacterial endocarditis and two by ruptured chordae tendineae without endocarditis, but though mitral incompetence (as evidenced by left atrial dilatation, "jet" lesions, or murmurs) was present in most cases, 16 patients had no symptoms related to their cardiac pathology.

The cases diagnosed clinically and at necropsy provided evidence both for and against all previously discussed pathogeneses, and it is suggested that mucoid degeneration of heart valves is a nonspecific tissue change and may result from many possible aetiological processes. 
I should like to thank the clinicians of the Central Middlesex Hospital and Dr. P. J. Mills of the Lister Hospital, Hitchin, under whose care most of these patients were admitted. I am also grateful to Dr. J. W. Lacey, Chelmsford Group Laboratory, and to Dr. C. R. Tribe, Wycombe General Hospital, for Cases 29 and 34, and to Mr. A. Booker for much of the photography.

\section{REFERENCES}

Barlow, J. B., and Bosman, C. K. (1966). Aneurysmal protrusion of the posterior leaflet of the mitral valve. Amer. Heart F., 71, 166.

- - - Pocock, W. A., and Marchand, P. (1968). Late systolic murmurs and non-ejection ("mid-late") systolic clicks. An analysis of 90 patients. Brit. Heart F., 30, 203.

Behar, V. S., Whalen, R. E., and McIntosh, H. D. (1967). The ballooning mitral valve in patients with the "precordial honk" or "whoop". Amer. F. Cardiol., 20, 789.

Criley, J. M., Lewis, K. B., Humphries, J. O’N., and Ross, R. S. (1966). Prolapse of the mitral valve: clinical and cine-angiocardiographic findings. Brit. Heart f., 28, 488.

Fernex, M., and Fernex, C. (1958). La dégénérescence mucoïde des valvules mitrales. Helv. med. Acta, 25, 694.
Goyette, E. M., and Palmer, P. W. (1953). Cardiovascular lesions in arachnodactyly. Circulation, 7, 373.

Linhart, J. W., and Taylor, W. J. (1966). The late apical systolic murmur. Amer. F. Cardiol., 18, 164.

McMillan, J. B., and Lev, M. (1959). The aging heart. I. Endocardium. $\mathcal{F}$. Geront., 14, 268.

Marchand, P., Barlow, J. B., du Plessis, L. A., and Webster, I. (1966). Mitral regurgitation with rupture of normal chordae tendineae. Brit. Heart f., 28, 746.

Oka, M., and Angrist, A. (1961). Fibrous thickening with billowing sail distortion of the aging heart valve. Proc. N.Y. St. Ass. publ. Hlth Lab., 46, 21.

Pomerance, A. (1967). Ageing changes in human heart valves. Brit. Heart f., 29, 222.

- (1968). Cardiac pathology and systolic murmurs in the elderly. Brit. Heart f., 30, 687.

$\longrightarrow$, and Whitney, J. C. (1969). In preparation.

Read, R. C., and Thal, A. P. (1966). Surgical experience with symptomatic myxomatous valvular transformation (the floppy valve syndrome). Surgery, 59, 173.

- - - , and Wendt, V. E. (1965). Symptomatic valvular myxomatous transformation. Circulation, 32, 897.

Shankar, K. R., Hultgren, M. K., Lauer, R. M., and Diehl, A. M. (1967). Lethal tricuspid and mitral regurgitation in Marfan's syndrome. Amer. F. Cardiol., 20, 122.

Stannard, M., Sloman, J. G., Hare, W. S. C., and Goble, A. J. (1967). Prolapse of the posterior leaflet of the mitral valve: a clinical, familial, and cineangiographic study. Brit. med. F., 2, 71. 